\title{
Should You Blame the Weather? The Influence of Weather Parameters, Month, and Day of the Week on Spring Herbaceous Plant Sales in the U.S. Midwest
}

\author{
Bridget K. Behe ${ }^{1,4}$ and Kristin L. Getter ${ }^{2}$ \\ Department of Horticulture, Michigan State University, A228 Plant and Soil \\ Sciences Building, East Lansing, MI 48824
}

\author{
Chengyan $\mathbf{Y u e}^{3}$ \\ Department of Horticultural Science and Applied Economics, University of \\ Minnesota, 316 e Classroom Office Building, 1994 Buford Avenue, St. Paul, \\ MN 55108
}

\section{Additional index words. economics, marketing, time series regression}

\begin{abstract}
Sales of many products, including umbrellas and skis, depend on weather conditions. Anecdotal evidence from plant producers and retailers indicate that their sales are also heavily reliant on weather conditions. Still, little published literature documents weather's influence on plant sales. Daily sales data of herbs, vegetables, and flowering annuals were acquired from 42 retail stores in Indiana, Ohio, and Michigan (which were divided into four regions based on zip code). The multisite Midwestern retailer sells food and household items year-round but seasonally sells plants in outdoor covered areas. The data were analyzed using time series regression and the model produced significant results, but the amount of variance captured by region, weather parameters, month, and day of the week was only $\approx \mathbf{4 0} \%$ for herbs and vegetables $(\mathrm{H}+\mathrm{V})$ and flowering annual plants (FA). Precipitation amount had no effect on sales of $\mathrm{H}+\mathrm{V}$ and FA, likely because the plants were merchandised under cover. Increasing units of sunshine lowered sales by $1 \% . \mathrm{H}+\mathrm{V}$ sales were greatest in the southeast Michigan region but for $F A$ were greatest in the mid-Michigan region. Lower minimum air temperature reduced sales for sales of both $\mathrm{H}+\mathrm{V}$ and $\mathrm{FA}$, whereas higher maximum air temperature increased sales. Sales were substantially higher in May and lower in June and July compared with April. Sales were higher in 2009 than 2007. Compared with Wednesday, sales were higher everyday and highest on Saturday. Day of week and month had a greater impact on sales than did any weather parameter. Thus, region, weather, month, and weekday do influence daily plant sales but did not account for most of the variability in 42 U.S. midwestern retail outlets.
\end{abstract}

Weather variability impacts every sector in the United States and has an impact on the U.S. gross domestic product (Larsen et al., 2011; NOAA, 2008). Specifically, parameters such as air temperature, relative humidity,

Received for publication 9 Sept. 2011. Accepted for publication 14 Nov. 2011.

We thank the Western Michigan Growers Association for providing funding for data collection and analysis and the generous donation of data by the anonymous growers and retailers. We also thank Drs. Marvin Miller and Brad Rowe for their editorial comments.

This article is dedicated to the memory of the late Dr. William H. Carlson, Professor Emeritus Michigan State University, who initiated this study.

${ }^{1}$ Professor.

${ }^{2}$ Postdoctoral Researcher

${ }^{3}$ Assistant Professor and Bachman Endowed Chair in Horticulture Marketing.

${ }^{4}$ To whom reprint requests should be addressed; e-mail behe@msu.edu. precipitation, and sunlight affect retail product sales (Murray et al., 2010; Starr-McCluer, 2000). Weather fluctuations can cause a shift in consumer demand for certain products (Niemira, 2005). For example, unusually dry weather may delay demand for umbrellas or suddenly cold weather can increase demand for products like mittens and hot chocolate.

Businesses take different approaches in dealing with weather and how it relates to sales. They may blame the weather on poor sales after the fact (Kleiderman, 2004) or buy insurance to hedge against their weatherrelated losses in sales (Chen and Yano, 2010). However, most business managers assume that future weather patterns will be the same as in previous years (Cawthorn, 1998), but those patterns do vary (Firth, 2009). The seasonality of weather is intertwined with the business cycle, which impacts product sales (Barsky and Miron, 1989). For instance, one turf and lawn care company earns $70 \%$ of its revenue in the second and third fiscal quarters annually (Radas and Shugan, 1998). Weather is also a significant determining factor for many products' beginning and ending sale dates. Therefore, yearly variability in weather may not only shift the selling season for a particular product, but also may make that season longer or shorter (Cawthorn, 1998).

Revenue forecasting can help manage uncertainty in sales and incorporating weather into these forecasting models improves prediction accuracy (Aghazadeh, 2007; Sivillo and Reilly, 2004). Cawthorn (1998) suggests a general approach for businesses that have never used weather in their forecasting. First, he suggests graphing the previous year's sales against weather data to see if the data are correlated or related (i.e., Did an increase in precipitation cause a decrease in sales?). Second, assess missed opportunities (i.e., Could more products have been sold had we used weather predictions for an early spring warm-up?). Finally, incorporate that assessment with predicted future weather to develop a going-forward planning strategy (i.e., What adjustments can we make to be better prepared to capitalize on missed opportunities?).

Much research has been done in other business sectors to incorporate weather into revenue forecasting such as electricity demand (Pedregal and Young, 2008), hotel management (Aghazadeh, 2007), and department stores (Steele, 1951); but little has been done with the sales of plants. Our objective was to define the relationship between several common weather variables and several categories of plant sales with the intention of developing simple models to help retailers and producers more predictably forecast plant sales. We hypothesized that several parameters would be related to plant sales. Precipitation and minimum air temperature would likely be negatively related to sales, whereas maximum air temperature and sunlight would likely be positively related to sales. In the Midwest, cool or cold air temperatures (minimums) would likely delay purchase of summer plants (herbs, vegetables, and annuals), whereas warmer air temperatures (maximum) would likely promote plant purchases. Day of week and sales would be related with greater sales on weekends and lower sales during weekdays. Finally, week number or month and sales would be positively related to a point (i.e., early in the season), and then a negative relationship would be observed (i.e., late in the season).

\section{Materials and Methods}

We obtained the voluntary participation of one Midwestern plant producer who provided daily scan-based sales data from 42 Midwestern stores in Indiana, Ohio, and Michigan. The producer was the only supplier of flowering annual, herb, and vegetable transplants to the stores. The 42 stores also sold food and household items. Their seasonal plant sales areas were relatively similar in size and product mix, attached to the store, 
but not climate-controlled except for overhead covering. Daily sales data were provided over a 12-week period (15 Apr. through 15 July) for 3 years (2007 through 2009) from each store in two categories: $\mathrm{H}+\mathrm{V}$ and FA. This time period was selected because, anecdotally, nearly all of the spring sales of herbs, vegetables, and annuals in this geographic area were most likely to occur in this timeframe each year.

Daily weather parameter measurements were purchased from AWIS Weather Services, Inc. (Auburn, AL). Measures included daily precipitation (hundredths of inches), minimum and maximum air temperatures, and a measure of sunlight (watt hours $/ \mathrm{m}^{2}$ ). Weather measures were provided from the most proximate weather station to the zip code of the retail store.

Time series linear regression analysis was used to analyze the data with the SAS (SAS 9.2; SAS Institute, Cary, NC) autoregressive procedure (Proc Autoreg). In examining the data, it was clear that there was a monthly or seasonal pattern as well as a day-of-the-week pattern, to sales. Therefore, month and dayof-the-week dummy variables were added to the data. In addition, because there may have been a year effect on data, dummy variables for year were also created. The data were also broken down into four region dummy variables based on zip code. To assess variable selection for inclusion in the final model, comparison of the adjusted $R^{2}$ was used. Because inclusion of all dummy variables would overparameterize the model, the lowest sales dummy variables were dropped and used as the base for estimation (April for the month dummy variable, Wednesday for the day-ofthe-week dummy variable, 2009 for the year dummy variable, and southwest Michigan for the region dummy variable).

We used an autoregressive error model to estimate the effects of weather parameters on plant sales. This method corrects for errors that are autocorrelated or heteroscedastic as a result of the time series nature of the data. Several generalized autoregressive conditional heteroscedasticity (GARCH) models were tested and the one with the lowest Akaike's information criterion was chosen (power GARCH). The dependent variable was the sales of different plant categories, whereas the independent variables included region (mid-Indiana, southwest Michigan, southeast Michigan, mid-Michigan), daily maximum temperature, minimum temperature, precipitation and solar radiation, month dummy variables (May, June, July), year dummy variables (2007 and 2008), and day of the week dummy variable (Thursday, Friday, Saturday, Sunday, Monday, Tuesday).

\section{Results}

Monthly average minimum ambient air temperatures during the data collection period ranged from 43.9 to $63.6^{\circ} \mathrm{F}$ (Table 1 ). Monthly average maximum ambient air temperatures ranged from 63.2 to $84.3{ }^{\circ} \mathrm{F}$. Monthly average precipitation ranged from
Table 1. Means of four weather parameters in 42 U.S. Midwestern stores included in model of weather parameter influence on daily plant sales of herbs and vegetables $(\mathrm{H}+\mathrm{V})$ and flowering annuals (FA).

\begin{tabular}{|c|c|c|c|c|c|c|}
\hline Region & $\mathrm{Yr}$ & Month & $\begin{array}{l}\text { Mean maximum } \\
\text { temperature }\left({ }^{\circ} \mathrm{F}\right)\end{array}$ & $\begin{array}{l}\text { Mean minimum } \\
\text { temperature }\left({ }^{\circ} \mathrm{F}\right)\end{array}$ & $\begin{array}{l}\text { Mean Sum of } \\
\text { Precipitation } \\
\text { (inches) }\end{array}$ & $\begin{array}{c}\text { Mean solar } \\
\text { radiation }\left(\mathrm{W} / \mathrm{m}^{2}\right)\end{array}$ \\
\hline \multicolumn{7}{|c|}{ Mid-Indiana $(\mathrm{n}=11)$} \\
\hline & \multirow[t]{4}{*}{2007} & April & 66.4 & 46.8 & 1.6 & 5375 \\
\hline & & May & 78.5 & 56.1 & 1.8 & 6476 \\
\hline & & June & 84.1 & 63.0 & 2.9 & 6701 \\
\hline & & July & 84.3 & 63.0 & 0.4 & 6938 \\
\hline & \multirow[t]{4}{*}{2008} & April & 67.3 & 46.5 & 0.6 & 5577 \\
\hline & & May & 67.6 & 49.5 & 5.1 & 5385 \\
\hline & & June & 82.3 & 63.1 & 8.3 & 6606 \\
\hline & & July & 80.8 & 63.6 & 3.8 & 6360 \\
\hline & \multirow[t]{4}{*}{2009} & April & 70.7 & 52.7 & 2.1 & 4916 \\
\hline & & May & 72.5 & 53.4 & 7.5 & 5733 \\
\hline & & June & 81.7 & 63.3 & 3.7 & 6546 \\
\hline & & July & 77.9 & 62.1 & 1.9 & 5151 \\
\hline \multicolumn{7}{|c|}{ Mid-Michigan $(\mathrm{n}=11)$} \\
\hline & \multirow[t]{4}{*}{2007} & April & 65.7 & 45.4 & 1.5 & 5019 \\
\hline & & May & 72.2 & 50.2 & 3.5 & 5748 \\
\hline & & June & 81.1 & 58.4 & 4.1 & 6460 \\
\hline & & July & 81.9 & 58.5 & 0.4 & 6685 \\
\hline & \multirow[t]{4}{*}{2008} & April & 68.5 & 45.1 & 0.5 & 5332 \\
\hline & & May & 65.4 & 43.9 & 1.9 & 5172 \\
\hline & & June & 78.6 & 58.9 & 5.3 & 5341 \\
\hline & & July & 78.6 & 58.9 & 2.6 & 6124 \\
\hline & \multirow[t]{4}{*}{2009} & April & 64.1 & 46.3 & 2.4 & 4028 \\
\hline & & May & 68.3 & 47.5 & 5.3 & 5248 \\
\hline & & June & 76.2 & 56.5 & 4.2 & 5613 \\
\hline & & July & 75.4 & 54.5 & 0.9 & 5511 \\
\hline
\end{tabular}

Southeast Michigan $(\mathrm{n}=11)$

$\begin{array}{lll}2007 & \text { April } & 66.1 \\ & \text { May } & 72.6 \\ & \text { June } & 82.2 \\ 2008 & \text { July } & 82.3 \\ & \text { April } & 69.6 \\ & \text { May } & 66.6 \\ & \text { June } & 80.2 \\ 2009 & \text { July } & 80.4 \\ & \text { April } & 68.7 \\ & \text { May } & 69.7 \\ & \text { June } & 77.4 \\ & \text { July } & 76.7\end{array}$

$\begin{array}{lll}47.1 & 1.5 & 4930 \\ 51.2 & 3.4 & 5824 \\ 60.6 & 3.4 & 6568 \\ 59.9 & 0.2 & 6522 \\ 46.7 & 0.5 & 5590 \\ 46.3 & 2.1 & 5331 \\ 60.6 & 4 & 5509 \\ 60.6 & 2.9 & 6031 \\ 46.9 & 0.9 & 4239 \\ 49.0 & 4.4 & 5068 \\ 57.8 & 5.3 & 5452 \\ 56.9 & 0.9 & 5309\end{array}$

Southwest Michigan ( $\mathrm{n}=9)$

$\begin{array}{clll}2007 & \text { April } & 65.3 & 45 \\ & \text { May } & 73.8 & 51.7 \\ & \text { June } & 81.7 & 60.0 \\ & \text { July } & 82.8 & 60.7 \\ & \text { April } & 67.6 & 44 . \\ & \text { May } & 65.5 & 45 \\ & \text { June } & 78.0 & 59 . \\ & \text { July } & 78.8 & 59.9 \\ & \text { April } & 63.2 & 46.2 \\ & \text { May } & 68.6 & 48 . \\ & \text { June } & 77.0 & 58.2 \\ & \text { July } & 74.8 & 56.7\end{array}$

0.2 to 8.3 inches. Mean solar radiation per month ranged from a low of $3583 \mathrm{~W} \mathrm{~h} / \mathrm{m}^{2}$ in Apr. 2009, to $6938 \mathrm{~W} \mathrm{~h} / \mathrm{m}^{2}$ in July 2007.

All of the region and weather parameters influenced FA and $\mathrm{H}+\mathrm{V}$ sales with the exception of precipitation (Table 2). Region, weather, and weekday accounted for only $\approx 40 \%$ of the variance in daily sales of this Midwestern multistore chain that merchandised plants under cover. Minimum air temperature slightly reduced $\mathrm{H}+\mathrm{V}$ and FA sales, whereas increased maximum air temperature slightly increased sales. Increasing sunlight reduced sales $1 \%$ per $\mathrm{W} \mathrm{h} / \mathrm{m}^{2}$.
All year and month dummy variables influenced the sales of plants. Sales of $\mathrm{H}+\mathrm{V}$ and FA were lower in 2007 compared with 2009 but similar to 2008 except for FA. Daily sales of $\mathrm{H}+\mathrm{V}$ were $\$ 44.56$ higher in May compared with April and \$16.91 lower in June and $\$ 17.53$ lower July. Daily sales of FA were $\$ 116.98$ higher in May and \$22.68 lower in June and \$27.14 lower in July. This was anticipated as a typical sales pattern for many annual transplants sold in the spring months in the Midwest. In addition, most day-of-theweek dummy variables had an influence on plant sales. Weekend sales (Saturday and 
Table 2. Multiple regression coefficients, significance, and goodness-of-fit results for a Midwestern multistore retail chain providing daily plant sales data for herbs and vegetables $(\mathrm{H}+\mathrm{V})$ and flowering annuals (FA) from 42 stores.

\begin{tabular}{lcc}
\hline & \multicolumn{2}{c}{ Coefficients $(P)$} \\
\cline { 2 - 3 } Variable & $\mathrm{H}+\mathrm{V}$ & $\mathrm{FA}$ \\
\hline Constant & $20.65(<0.0001)$ & $27.75(<0.0001)$ \\
Region mid-Indiana & $-0.56(<0.0001)$ & $-3.08(<0.0001)$ \\
Region southeast Michigan & $0.97(<0.0001)$ & $0.46(0.1276)$ \\
Region mid-Michigan & $0.27(0.0409)$ & $1.55(<0.0001)$ \\
Maximum air temperature $\left({ }^{\circ} \mathrm{F}\right)$ & $0.09(<0.0001)$ & $0.19(<0.0001)$ \\
Minimum air temperature $\left({ }^{\circ} \mathrm{F}\right)$ & $-0.06(<0.0001)$ & $-0.14(<0.0001)$ \\
Precipitation $($ inches $)$ & $0.17(0.3804)$ & $-0.19(0.6945)$ \\
Solar radiation $\left(\mathrm{W} / \mathrm{m}^{2}\right)$ & $-0.01(<0.0001)$ & $-0.01(0.0010)$ \\
May & $44.56(<0.0001)$ & $116.98(<0.0001)$ \\
June & $-16.91(<0.0001)$ & $-22.68(<0.0001)$ \\
July & $-17.53(<0.0001)$ & $-27.14(<0.0001)$ \\
2007 & $-4.82(<0.0001)$ & $-3.65(<0.0001)$ \\
2008 & $0.67(0.0003)$ & $0.18(0.5258)$ \\
Thursday & $0.06(0.7624)$ & $-0.80(0.0270)$ \\
Friday & $0.29(0.1360)$ & $-0.36(0.4861)$ \\
Saturday & $3.12(<0.0001)$ & $3.49(<0.0001)$ \\
Sunday & $2.73(<0.0001)$ & $3.38(<0.0001)$ \\
Monday & $0.48(0.0671)$ & $0.75(0.2045)$ \\
Tuesday & $-0.34(0.1583)$ & $-1.30(0.0029)$ \\
Adjusted $R^{2}$ & 0.387 & 0.414 \\
\hline & &
\end{tabular}

Sunday) of $\mathrm{H}+\mathrm{V}$ and $\mathrm{FA}$ were higher than weekday sales. Saturday sales were the single highest sales day for $\mathrm{H}+\mathrm{V}$ and $\mathrm{FA}$. The second highest sales of FA and $\mathrm{H}+\mathrm{V}$ occurred on Sunday and third highest on Monday. Saturday sales of $\mathrm{H}+\mathrm{V}$ were $312 \%$ higher than Wednesday sales and 349\% higher for FA sales.

Additionally, we tested lags of up to $7 \mathrm{~d}$ on daily sales and found that nearly all lags were not significant or had very minor influences and therefore were excluded from the final model. So, sales of the prior days did not influence the subsequent day's sales.

\section{Conclusions}

Weather parameters do influence plant sales, but not to as great an extent as anecdotal evidence might suggest because the model accounted for $\approx 40 \%$ of the sales variance. Sales of $\mathrm{H}+\mathrm{V}$ and FA were higher in 2009 compared with 2007; sales were also higher in May but lower in June and July compared with April. Day of the week had a more substantial effect than weather parameters on sales of FA and $\mathrm{H}+\mathrm{V}$. Because the dependent variable was dollars, the coefficients represent increases or decreases in daily sales of the two plant categories in dollars and cents. In the Midwestern multistore retailer, minimum air temperature and sunlight had a slight negative impact on $\mathrm{H}+\mathrm{V}$, reducing daily sales by 1 and 9 cents per unit, respectively, and FA sales, reducing them by 14 and 1 cents per unit, respec- weather parameters. In U.S. regions where plant sales are less concentrated in a few weeks, the influence of weather may also be different. Until then, the best predictor of FA and $\mathrm{H}+\mathrm{V}$ sales will be the threefold or greater effect Saturday has on sales and the tremendous impact May has.

\section{Literature Cited}

Aghazadeh, S. 2007. Revenue forecasting models for hotel management. J. Business Forecasting. p. 33-37.

Barsky, R.B. and J.A. Miron. 1989. The seasonal cycle and the business cycle. J. Polit. Econ. 97:503-534.

Cawthorn, C. 1998. Weather as a strategic element in demand chain planning. The J. of Business Forecasting Methods \& Systems. 17:18-21.

Chen, F.Y. and C.A. Yano. 2010. Improving supply chain performance and managing risk under weather-related demand uncertainty. Manage. Sci. 56:1380-1397.

Firth, B. 2009. Identifying and quantifying how weather influences consumer behavior. White paper, Weather Trends International. $<$ http:// www.wxtrends.com/files/whitepapers/identify_ and quantify_weather_influences_on human behavior.pdf $>$.

tively. However, each degree increase in maximum air temperature increased daily sales 9 or 19 cents per day. Precipitation was not significant in either model. Consistently, $\mathrm{FA}$ and $\mathrm{H}+\mathrm{V}$ sales were highest on Saturday, enhancing daily sales by $\$ 3.12$ or $\$ 3.49$. Generally, FA and $\mathrm{H}+\mathrm{V}$ sales were higher on weekend days (Saturday and Sunday) compared with weekdays. For practical inventory and labor management, weekday plays a greater and more easily predictive role on sales than weather. Deliveries and workers should be scheduled to anticipate the high plant sales on Saturday. Given the magnitude of effect of day of the week on sales, a second delivery might be made during the weekend to further enhance those sales.

These data indicate there is a modest relationship between weather parameters and sales of FA and $\mathrm{H}+\mathrm{V}$ but a stronger and more predictable relationship between month and day of the week on sales. Given the low amount of variance accounted for by the model, it would be of little value to help predict sales. Growers and retailers now have evidence that it is not just the weather that accounts for the wide variability in $\mathrm{H}+\mathrm{V}$ and FA sales. Day of the week plays a more substantial role. These results should encourage additional models to be tested in other regions of the United States with additional independent and multilocation plant retailers. The amount of covered sales area should be included in future models, because the researchers hypothesize that covered area likely influenced the impact of
Kleiderman, A. 2004. Soggy summer spells boardroom gloom. BBC News (25 Sept.). <http:// news.bbc.co.uk/2/hi/business/3686742.stm>.

Larsen, P.H., M. Lawson, J.K. Lazo, and D.M. Waldman. 2011. Sensitivity of the U.S. economy to weather variability. $<$ http://www.sip. ucar.edu/publications/PDF/2010_01_04_US_ Weather_Sensitivity_Main Document.pdf>.

Murray, K.B., F.D. Muro, A. Finn, and P.P. Leszczyc. 2010. The effect of weather on consumer spending. J. Retailing Consum. Serv. 17:512-520.

NOAA. 2008. Economic Statistics for NOAA, Sixth Edition. Office of Program Planning and Integration, National Oceanic and Atmospheric Administration. <http://www.ppi.noaa. gov/wp-content/uploads/2011/05/2008_06_04_ EconStatsFinal.pdfs.

Niemira, M.P. 2005. Weather matters. Intl. Council Shopping Centers Res. Rev. 12:23-27.

Pedregal, D.J. and P.C. Young. 2008. Development of improved adaptive approaches to electricity demand forecasting. J. Oper. Res. Soc. 59: 1066-1076.

Radas, S. and S.M. Shugan. 1998. Seasonal marketing and timing new product introductions. J. Mark. Res. 35:296-315.

Sivillo, J.K. and D.P. Reilly. 2004. Forecasting consumer product demand with weather information: A case study. J. Bus. Forecasting Methods \& Systems. 23:22-29.

Starr-McCluer, M. 2000. The effects of weather on retail sales. Finance and Economics Discussion Series Working Paper 2000-08. Federal Reserve Board of Governors, Washington, DC.

Steele, A.T. 1951. Weather's effect on the sales of a department store (pre-1986). J. Marketing 15:436-443. 